African Crop Science Journal by African Crop Science Society is licensed under a Creative Commons Attribution 3.0 Uganda License. Based on a work at www.ajol.info/ and www.bioline.org.br/cs DOI: https://dx.doi.org/10.4314/acsj.v28i2.11

\title{
SMALLHOLDER ORANGE FARMER ACCESS TO MARKETS IN UGANDA
}

\author{
H. KONGAI, J. MANGISONI, G. ELEPU ${ }^{1}$, E. CHILEMBWE and D. MAKOKA
}

Bunda College of Agriculture, Lilongwe University of Agriculture and Natural Resources, P. O. Box 219, Bunda, Lilongwe, Malawi

${ }^{1}$ College of Agricultural and Environmental Sciences, Makerere University, P. O. Box 7062, Kampala, Uganda

Corresponding author: hellenbiruma@gmail.com

(Received 4 September 2019; accepted 11 June 2020)

\begin{abstract}
Orange (Citrus sinensis L.) is a major dietary component globally, responsible for supplying nutrients and phytochemicals of biological and health influence such as minerals, vitamins, fiber, flavonoids, limonoids, and carotenoids and antioxidant. It accounts for more than $50 \%$ of the citrus fruits produced world-over. It is a popular fruit in sub-Saharan Africa, though its level of consumption per capita is by global standards very low. In Uganda, orange production is mostly concentrated in eastern and northern parts; mostly grown by small holder farmers who are plagued by a milliard of production and marketing constraints. The objective of this study was to evaluate the effect of institutional, infrastructural and socio-economic factors on smallholder access to orange markets in Uganda. The study was conducted in Kaberamaido, Kumi and Soroti Districts in eastern Uganda, using cross sectional data, during 2011-2012. Probit model results showed that the key institutional factor that affected smallholder access to markets was institutional belonging; the infrastructural factors entailed ownership of mobile phone and location of household; while age of household head, household size and output price constituted the socio-economic factors. Mobile phone, household size and age of household head elicited the highest effect on the probability for smallholder market access, and the magnitude of effect is shown by flexibilities of $0.5,-0.06$ and 0.02 , respectively. Tobit model estimates showed that market information, and household location constituted institutional and infrastructural factors affecting market access, respectively; while age of trees, output, output price and occupation of household head constituted the socio-economic factors. The critical factors that affect the extent of market access include location, market information, primary occupation of household head and quantity of output as shown by flexibilities of $-0.6,0.5,0.5$, and 0.03 , respectively. Based on the Probit and Tobit model estimates, market information, mobile phone and quantity of outputs constitute critical institutional, infrastructural and socio-economic factors that affect smallholder market access. Therefore, opportunity for unlocking the potential for smallholders to access orange markets exists in boosting the level of output and facilitating linkage to markets.
\end{abstract}

Key Words: Citrus sinensis, infrastructural, institutional 
L'orange (Citrus sinensis L.) est un aliment majeur à l'échelle mondiale, qui contient des nutriments et des composés phytochimiques d'influence biologique et sanitaire tels que les minéraux, les vitamines, les fibres, les flavonoïdes, les limonoïdes et les caroténoïdes et les antioxydants. Il comprend plus de $50 \%$ des fruits des agrumes qui sont cultivés dans le monde. C'est un fruit populaire en Afrique subsaharienne, bien que son niveau de consommation par habitant soit très bas par rapport aux normes mondiales. En Ouganda, la production d'orange est principalement concentrée dans l'Est et le Nord de l'Ouganda; principalement par de petits agriculteurs qui souffrent d'un milliard de contraintes de production et de commercialisation. L'objectif de cette étude était d'évaluer l'effet des facteurs institutionnels, infrastructurels et socio-économiques sur l'accès des petits agriculteurs aux marchés d'orange en Ouganda. L'étude a été faite dans les districts de Kaberamaido, Kumi et Soroti dans l'Est de l'Ouganda à l'aide de données transversales, au cours de la période 2011-2012. Les résultats du modèle Probit ont montré que le facteur institutionnel clé qui affectait l'accès des petits agriculteurs aux marchés était l'appartenance institutionnelle, les facteurs d'infrastructure impliquaient la propriété du téléphone portable et l'emplacement du ménage, tandis que l'âge du chef de ménage, la taille du ménage et le prix de production qui constituaient les facteurs socio-économiques. Le téléphone portable, la taille du ménage et l'âge du chef de ménage provoquent l'effet le plus élevé sur la probabilité d'accès au marché des petits agriculteurs et l'immensité de l'effet est indiquée par des flexibilités de $0,5,-0,06$ et 0,02 , respectivement. Les estimations du modèle Tobit ont montré que les informations sur le marché et l'emplacement des ménages constituaient des facteurs institutionnels et infrastructurels affectant respectivement l'accès aux marchés, tandis que l'âge des arbres, la production, le prix de production et l'occupation du chef de ménage constituaient les facteurs socio-économiques. Les facteurs critiques qui affectent l'étendue de l'accès au marché comprennent l'emplacement, les informations sur le marché, l'occupation principale du chef de ménage et la quantité de production, comme le montrent les flexibilités de -0,6, 0,5, 0,5 et 0,03, respectivement. En se basant sur des estimations du modèle Probit et Tobit, les informations sur le marché, le téléphone portable et la quantité de production constituent des facteurs institutionnels, infrastructurels et socio-économiques critiques qui affectent l'accès des petits exploitants aux marchés. Par conséquent, il est possible de libérer le potentiel des petits agriculteurs d'accéder aux marchés d'orange en augmentant le niveau de production et en facilitant les liens avec les marchés.

Mots Clés: Citrus sinensis, infrastructurel, institutionnel

\section{INTRODUCTION}

Orange (Citrus sinensis L.) is a major dietary component globally, responsible for supplying nutrients and phytochemicals of biological and health influence such as minerals, vitamins, fiber, flavonoids, limonoids and carotenoids, and antioxidant (Turner and Burri, 2013). It accounts for more than $50 \%$ of the citrus fruits produced world-over. It is a popular fruit in sub-Saharan Africa, and its level of consumption per capita is rising (Allegra et al., 2019). Orange production in Uganda has been steadily rising from 24,000 metric tonnes in 1994 to about 5,769,177 metric tonnes in 2015 (Kongai et al., 2018). The bulk of the oranges are traded in domestic and regional fresh fruits markets (Kongai, 2017), with commonly marketed varieties include Sweet Valencia, Washington Naval, Hamlin and the local orange. Other varieties include American Jaffer, Mediterranean sweet, Denmark and Lomati.

The main domestic market outlets include the rural, urban and road side markets, kiosks and supermarkets (Alobo et al., 2011). On the other hand, regional markets include Kenya, Rwanda and South Sudan (Alobo, 2011; Ekesi, 
2011; Kongai, 2017). In spite of the existence of significant orange fruits trade locally and regionally, data pertinent to the trade transactions are largely missing due to informal in-country and cross-border trade (Ekesi, 2011; Kongai et al., 2017).

Selling and buying of oranges is generally done on cash basis, which is good for smallholders whose operations are usually characterised by low cash outlays. In some instances, upfront payments are made, especially to farmers to book pre-mature fruits for collection at a later date, from production areas (Kongai et al., 2018). With the enterprise being dominated by smallholders operating fragmented orchards over a widely spread geographical area, bulking and transportation of produce become costly and challenging. Yet, just like any other highly perishable agricultural product, prices are devastatingly low during peak harvest periods, compelling farmers to delay sale of produce, amidst inappropriate storage conditions leading to great losses due to over-ripening and rotting.

Processing of orange fruits into juice and other products, would be the most logical option; unfortunately this is limited by underdeveloped juice processing industry. The existing industrial processors of orange fruit juice in Uganda, for instance Jakana Foods Limited, Britania Allied Industries and the recently installed Soroti Fruit Factory, either have limited capacity to absorb the steadily increasing orange fruits output, or import raw materials for juice processing from elsewhere (Kongai et al., 2018). Besides, smallholders face various constraints, including weak linkages with markets and limited or inefficient quality enhancement (Sonko et al., 2005; Alobo et al., 2011). Consequently, smallholders fail to realise the full benefit of commercialising orange fruits production.

The Government of Uganda instituted measures to support development and growth of the citrus industry in the country (PMA, 2009; Kongai, 2017). For instance, the Government supported institutionalisation of smallholder farmers to enhance their linkage to output markets through the Marketing and Agro Processing Strategy (MAPS) (Ministry of Tourism, Trade and Industry, 2005). This contributed to formation of farmer institutions such as Teso Tropical Fruit Growers Association (Kongai et al., 2017). The Association has facilitated organisation of smallholders for acquisition of services, load bulking and advocacy for production and marketing.

Despite, the prevailing interventions, smallholders have only been able to sell on average less than $20 \%$ of their produce due to limited market access (Kongai et al., 2011). Yet like any other agri-based entrepreneurs, the key concern for smallholder orange farmers is not only bulk productivity, but also greater cash incomes, implying that sustaining growth and development in orange production largely depends on expansion of market opportunities (Diao and Hezel, 2004; GabreMadhin and Haggblade, 2004), thus enhancing market access, a necessary condition for agricultural and rural development in Uganda (Hammouda et al., 2005). Therefore, the objective of this study was to evaluate the effect of institutional, infrastructural and socioeconomic factors on orange smallholders' market access in Uganda.

\section{METHODOLOGY}

Study area. Primary data were collected from citrus farming households in Kaberamaido, Kumi and Soroti districts located in Kyoga Plains Agricultural Zone, in eastern Uganda. Kyoga Plains Agricultural Zone has a flat terrain with isolated hills and shallow valleys (Nahamya and Mitala, 2004). The Zone experiences two rain seasons in a year, ranging from 1215-1328 $\mathrm{mm}$ per annum. Temperatures in the Zone range from $15-32.5$ ${ }^{\circ} \mathrm{C}$; while altitude ranges from $914-1,800 \mathrm{~m}$ ASL (Nahamya and Mitala, 2004; UDC, 2012). The environmental conditions apparently favour orange production (PMA, 2009); hence 
orange production is one of the Zone's priority enterpriss (Kongai et al., 2018).

This study was conducted in three districts of Kaberamaido, Kumi and Soroti, all in the Teso sub-region; which otherwise comprises of a total of 8 districts (Uganda Investment Authority, 2016). These were purposely selected considering the intensity of orange production in the region (UDC, 2012).

Sampling procedure. Drawing from Palinkas et al. (2015), smallholder orange producers were selected using multistage sampling criteria to participate in the study. Initially, the Zone and districts were purposively selected; followed by four sub-counties per district which were randomly selected. In order to minimise consequent bias arising from use of purely purposive sampling, a blend of respondent driven sampling (RDS) and random sampling criteria were used to select respondent households.

Respondent driven sampling criteria is a blend of snowball sampling approach that has been used to minimise selection bias in hard to reach populations (Johnston and Sabin, 2010). Within the blend, RDS criteria was used to ensure selection of only orange farming households; while random sampling criteria was applied at the initial point at every district and subcounty to identify the first respondent so as to ensure inclusion of respondents from target sub counties and more remote areas, respectively.

The process involved random selection of the initial respondent household at each subcounty, who provide information (list) to guide the selection of the subsequent respondent household within the sub-county. This process was repeated in each sub-county until new information was exhausted and the target sample of 446 households, determined using Glenn (2009) formula, was reached.

Data capture and analysis. Various proxies have been used to measure market access.
Nee and Young (1991) used a factor score combining the distance to a standard market town, distance to county town and distance to the nearest city as a proxy for market access. Applying Ordinary Least Squares technique on cross sectional data, they demonstrated that level of entrepreneurship significantly affected market access. They also observed that factors associated with market access such as information networks, transportation conditions, and long-term village alliances that sustained trust contributed to the differences in the level of entrepreneurship, and thus to market access. Similarly, Kamara (2004) estimated OLS using time taken to travel to a market as a market access proxy. Findings showed that $10 \%$ improvement in market access, ceteris paribus, led to about $1.7 \%$ increment in aggregate productivity. Although distance to market site or time taken to reach a market site were mainly used as proxies for market access, these measures have been found inadequate to capture commodity specific market access conditions (Rudaherwana, 2003). For instance, these measures do not consider the fact that smallholders may take produce to a physical market, but fail to find buyers or even sell only a proportion of the commodity transported to a market site. According to Baltenweck and Staal (2007), commodity specific market access problems of necessity should look beyond the generic measures. For that reason, the current study used actual quantity sold as a proxy for market access measurement.

Basing on actual quantity of orange fruits sold as a market access proxy, the dependent variable used to estimate the effect of institutional, infrastructural and socioeconomic factors on market access of necessity had to be defined in two forms to measure the probability of market access and the level of market access. The variable used to measure probability for market access was defined as a dichotomous variable and specified as: 
$Y_{i}=\{1$ if a household sold output O if a household did not sell any of its output

Equation 1

Drawing from Cameron and Trivedi (2005), a Probit model was used for determining the effect of institutional, infrastructural and socioeconomic factors on market access and was defined as:

$Y_{i}^{*}=\mathrm{a}+\mathrm{b} X_{i}^{*}+\varepsilon_{i}^{*}$ Equation 2

Where:

$\mathrm{X}^{*}$ are independent variables representing institutional, infrastructural and socioeconomic factors.

Cognizant of the fact that the parameter estimates obtained from the Probit regressing are latent model parameters, which cannot be interpreted as flexibilities, the Probit marginal effects were obtained using the formula: $\frac{d p_{i}}{d x_{i}}=\emptyset\left(\mathrm{x}_{\mathrm{i}}^{\prime} \beta\right) \beta_{\mathrm{i}}=\emptyset\left({ }^{\phi-1}\left(\mathrm{p}_{\mathrm{i}}\right)\right) \beta_{\mathrm{i}}$

Equation 3

Where:

$\mathrm{p}_{\mathrm{i}}=\Phi\left(\mathrm{x}_{\mathrm{i}}^{\prime} \beta\right)$

The Probit model was estimated in two forms, controlled and uncontrolled Probit,using district as a control factor for fixed effects. This was aimed at evaluating across and within district variations in market access. The estimated models' goodness of fit measured by Pseudo $\mathrm{R}^{2}$ were 5 and $22 \%$, for the factor controlled and non-factor controlled Probit models, respectively. The probability of $\mathrm{F}$ for both models was 0.000 . Overall, the uncontrolled Probit model provided improved estimates over the fixed factor controlled model so its parameters were used to explain variability in the probability for smallholder market access (Table 1).

TABLE 1. Probit model estimates of factors affecting the probability for smallholder access to orange markets in Uganda

\begin{tabular}{lccccc}
\hline Variable & Coefficient & $\begin{array}{c}\text { Marginal } \\
\text { effects }\end{array}$ & $\begin{array}{c}\text { Robust } \\
\text { std. Err }\end{array}$ & $\mathrm{Z}$ & $\mathrm{P}>\mid \mathrm{zl}$ \\
\hline Distance to market & -0.183 & -0.0232 & 0.0329 & -0.71 & 0.478 \\
Gender of head & 0.076 & 0.009 & 0.0413 & 0.21 & 0.836 \\
Mobile phone & $0.470^{* *}$ & 0.0615 & 0.0245 & 2.67 & 0.008 \\
Primary education & 0.16 & 0.0196 & 0.0217 & 0.9 & 0.369 \\
Formal employment & 0.172 & 0.02 & 0.0275 & 0.68 & 0.497 \\
Age of household head & $0.020^{* *}$ & 0.0025 & 0.0011 & 2.15 & 0.032 \\
Fruiting trees & 0.003 & 0.0003 & 0.0002 & 1.41 & 0.157 \\
Household size & $-0.058^{* *}$ & -0.0073 & 0.0034 & -2.29 & 0.022 \\
Extension & 0.226 & 0.0309 & 0.0279 & 1.19 & 0.234 \\
Price & $0.004^{* * *}$ & 0.005 & 0.0001 & 5.09 & 0 \\
Location (district 3) & $1.520^{* * *}$ & 0.1068 & 0.022 & 3.94 & 0 \\
Institutional belonging & $-0.0442^{* *}$ & -0.0636 & 0.0299 & -2.29 & 0.022 \\
Constant & $-2.659^{*}$ & & & -1.83 & 0.068 \\
\hline
\end{tabular}

Pseudo R2 = 0.22, Log Pseudolikelihood = -125.414, Wald Chi2 $(11)=51.83$, Prob Chi2 = 0.000; *** = $\mathrm{P}<0.01, * *=\mathrm{P}<0.05, *=\mathrm{P}<0.10$ 
The dichotomous market access variable yielded self-selection into the sample; thus censoring data due to the presence of households that did not sell any of their output. This necessitated specification of the second form of market access variable, the continuous market access variable, to enable estimation of a model suited for censored data. So, the dependent variable was also defined as continuous variable representing actual quantity of output sold. According to Woodridge (2002) and Cameron and Trivedi (2005), the most appropriate model for censored dependent variable analysis is the Tobit model, hence use of this model for estimation of parameters demonstrating the effect of infrastructural, institutional, and socio-economic factors on the extent of smallholder orange market access. The Tobit model was defined as follows:

$y_{i}=\left\{\begin{array}{l}y^{*} \text { if } y^{*}>0 \\ 0 \text { if } y^{*} \leq 0\end{array}\right.$ Equation 4

The model estimation procedure uses the likelihood function specified as:

$\ln \mathrm{L}=\sum_{i=1}^{N}\left\{d i\left(-\ln \sigma+\ln \emptyset\left(\frac{y_{i}-x_{i} \beta}{\sigma}\right)\right)+\right.$ $\left.(1-d i) \ln \left(1-\emptyset\left(\frac{x_{i} \beta}{\sigma}\right)\right)\right\} \ldots \ldots$. Equation 5

So, the analytical model used for Tobit parameters estimation was specified as:

$\mathrm{Y}_{\mathrm{i}}=x_{i} \beta+\varepsilon_{i}$ Equation 6

Where:

$\varepsilon_{i} \sim \mathrm{N}(0, \sigma 2) . \mathrm{Y}$ is a latent variable that is observed for values greater than 0 and censored otherwise.

The variables used in modelling market access comprised of the following: Institutional (institutional belonging, extension and market information), infrastructural (mobile phone, location of household and distance to nearest market site) and socioeconomic factors (age, gender, education and occupation of household head, household size, output, number and age of trees, orange hecterage and output price).

Both Probit and Tobit models do not provide consistent estimates in the presence of any form of heteroscedasticity, omitted variables (even if they are orthogonal to the included ones), non- linearity of the form of index or an error in distribution assumptions (Green, 2012). To ensure estimation of consistent parameters, therefore, Spearman correlation coefficients were generated and examined to obtain understanding of association among variables (Dormann et al., 2013). The highly correlated variables were not included in the model so as to deal with the multicollinearity problem, which would otherwise yield inconsistent estimates. Data were also subjected to normality tests using Shapiro Frarcia $\mathrm{W}$ ' test and all variables were significant at $\mathrm{p}<0.001$ implying that the data assumed a normal distribution.

\section{RESULTS AND DISCUSSION}

Probability of market access. Results showed that institutional factor (institutional belonging), infrastructural factors (mobile phone and location of household) and socioeconomic factors (output price, household head's age and household size) significantly affected the probability of market access (Table 1). Overall, output price, mobile phone and household head's age showed positive effect contrary to household size and institutional belonging that showed a negative effect (Table 1).

Output price had a positive and significant effect on the probability of market access (Table 1). High market prices usually provide incentives for farmers to search for market. Besides, high market prices facilitate increased production as they enable farmers to secure additional resources to invest in production, thus boosting supply loads, which in itself attracts buyers because rational traders usually 
opt for transactions that minimise marketing (assembly and transportation) costs. According to the estimated model's marginal effects, $1 \%$ increase in orange fruits price results to $0.04 \%$ increase in the probability for market access. A study in Uganda by Komarek (2010) similarly showed that output price positively affected both the probability and extent of banana farmers market access. In Kenya, output price was found to positively affect the extent of maize and kale market access in peri-urban areas (Komarek, 2009; Omiti et al., 2010). Kyaw et al. (2018) demonstrated that farmers that obtained a high output price produced more and were able to sell more; implying that strategies that enhance output price are inevitable for improved smallholder orange market access.

Owning a mobile phone had the highest positive effect on the probability of market access. Marginal effects showed that possession of mobile phone (contact) increases a household's probability for market access by $6 \%$. In Uganda, agricultural commodity markets are characterised by information asymmetry, whereby traders are more informed about prices than farmers (Ayoki, 2007). This yields high information search costs as farmers endeavor to determine the current market price, as well as quantity and quality requirements among others. Orange farmers used mobile phones to establish linkages between them and commission agents/ traders, and effecting preliminary negotiations on trade transactions. This probably explains why the phone had the highest positive effect on smallholder market access. Besides, mobile phones were used by farmers to communicate among themselves for load bulking or general information sharing. This implies that possession of mobile phones (contacts) affords smallholders linkage to traders and market information at reduced costs, which ultimately enhances their probability of accessing markets.

Zivenge and Karavina (2012) similarly observed that mobile phone ownership facilitated farmers' acquisition of real time market prices for tomato, as such mobile phones motivate informal market participation. In that regard, Mwakaje (2010) emphasized that use of information and communication technology to access market information significantly affects sales. Therefore, facilitating smallholder access to and possession of mobile phones would help enhance the probability for market access.

Age of the household head had a positive and significant effect on the probability for market access implying that the older the household head the higher the probability for market access (Table 1). This could be because older farmers possess more knowledge and experience in marketing agricultural products compared to the younger ones (Gani and Adeoti, 2011). This was also demonstrated by Cunningham et al. (2008) in a study where experience on farm was found to be directly related to age of household head market participation.

In contrast, Mahele (2007) and Abafita et al. (2016) found that age of household head was negatively related to market participation, because younger household heads tended to have better ability to obtain, process and use market information compared to older ones. Nevertheless, empowerment for smallholders in regard to acquisition and use of market information would be key to facilitating smallholder market access.

Belonging to institutions showed a significant but negative effect on the probability of access to orange markets (Table 1). This could be due to the nature of institutions that orange farmers belonged to, institutional leaderships, together with the farmers' limited decision making and business management capacity. Most of the groups that orange farmers belonged to came to existence as part of non-government organisations (NGOs) or government interventional activities with the main aim to enhance social welfare (Mwesigwa, 2018). Such groups did not give much emphasis to knowledge and skills required to enhance business operations, and thus market access. This was observed for 
instance, where farmer groups encouraged members to negotiate for higher prices and when the desired prices were not realised, farmers kept the fruits till they over-matured, resulting to substantial fruit damage. Earlier work in Zimbabwe similarly, showed that institutions that focused on social development, rather than business did not necessarily facilitate farmers access to market (Zivenge and Karavina, 2012). However, belonging to an institution better positions smallholders to reduce transaction costs for market exchanges, obtain necessary market information, secure access to new technologies and tap into high value markets; thus enhancing their market access (Markelova and Meinzen, 2009; Ouma and Jagwe, 2010). This observation highlights the need to facilitate development of farmer institutional capacity to guide entrepreneurship skills development.

Household size had a negative relationship with the probability of market access (Table 1), suggesting that the larger the household size, the lower the probability for market access. Generally, a larger household size constrains household cash resources, leaving a bare minimum available for market search and re-investment. So, our result depicts that the pressure exerted on household income by household size reduces the probability for the household to access markets.

Nevertheless, the household size effect on market access has been found to be bidirectional (Siziba et al., 2011; Obi and Pote, 2012). For instance, a larger household size may increase labour available for increasing output load, and ultimately expand chances for market access (Obi and Pote, 2012). So, empowerment of household members to take advantage of benefits accruing to the household size by appropriately utilising available time and labour resources for improved market access is necessary.

Geographical location of orange farms also had a significant effect on farmer access to organge markets (Table 1). Households located in Kaberamaido District had higher probability for market access compared to those located in Kumi and Soroti districts (Table 1). Kaberamaido District is a breakaway district from Soroti and is relatively less developed (Onek, 2014). However, its location on the highway from Kampala and other urban centres in the eastern region, plus its proximity to Sudan, a country which is currently sourcing most of its food supplies from Uganda, may be contributory to its higher probability of market access. Therefore, effective cooperation and coordination among farmers in and across Kaberamaido, Kumi and Soroti districts would create linkages and synergies that can enhance smallholder orange market access.

Extent of market access. Tobit model estimates showed that the institutional factor (market information), infrastructural factor (location of household) and socio-economic factors (orange output, output price, age of trees, and the primary occupation of household head) significantly affected the level of market access by orange farmers. Usually, a rational trader's primary objective is to maximise profits. In pursuit of profit maximisation amidst trade operations characterised by fragmented loads spread over a wide area, traders opt to purchase merchandise from sellers offering larger loads. This enables the traders to strategically minimise assembly costs. This probably explains the 0.3 units increase in the level of market access triggered by a one unit increase in output, demonstrated by the current study finding. So implementation of strategies that boost output loads would facilitate smallholder access to market.

The price of orange fruits showed a positive and very significant effect on the extent of market access, though its magnitude was quite small (Table 2). The likely reason for the small price coefficient could be inaccuracy in price data measurement resulting from nonstandardised output measurements. Price data used in this study were collected based on a polythene bag standard of measurement to 
TABLE 2. Factors affecting the extent of orange market access in eastern Uganda

\begin{tabular}{llccc}
\hline Variable & Coefficient & Standard error & $\mathrm{T}$ & P-value \\
\hline Total output & $0.02725^{* *}$ & 0.01269 & 2.15 & 0.032 \\
Average age of trees & $0.08973^{* * *}$ & 0.28458 & 3.15 & 0.002 \\
Age of household head & 0.00759 & 0.01086 & 0.7 & 0.485 \\
Output price & $0.00004^{* * *}$ & $7.90 \mathrm{E}-06$ & 4.44 & 0 \\
Hectarage & 0.49939 & 0.44098 & 1.13 & 0.258 \\
Market information & $0.48732^{*}$ & 0.27367 & 1.78 & 0.076 \\
Location (Soroti) & $-0.60145^{* *}$ & 0.25737 & -2.34 & 0.02 \\
Household heads primary occupation & $0.58924^{* *}$ & 0.26599 & 2.22 & 0.027 \\
Household size & -0.0306 & 0.04793 & -0.64 & 0.523 \\
Constant------- & $-2.218297 * * *$ & 0.83655 & -2.65 & 0.008 \\
\hline
\end{tabular}

$* * *=\mathrm{P}<0.01, * *=\mathrm{P}<0.05, *=\mathrm{P}<0.10 ;$ Pseudo $\mathrm{R} 2=13 \%$

emulate farmer practice, though it was later found out that the quantities contained in the polythene bags varied. For instance, bags were filled to a "egoropa" level, which could be equated to anything above $80 \mathrm{~kg}$ capacity of ordinary bags.

Access to market information similarly increased the level of market access by 0.5 units (Table 2). This could be because farmers that had market information were able to plan for production and disposal of larger quantities of their produce, compared to those who did not have access to market information (Kongai, 2017). The information obtained by farmers mainly related to current prices and quantities required by different output buyers. The information was obtained from extension agents, traders, NGOs, radios and/or fellow farmers. This information enabled farmers to link-up with output buyers and arrange for appropriate harvests, thus facilitating appropriate short term decisions. It was, however, observed that information to facilitate long term decisions was missing. Therefore, in order to enhance smallholder access to citrus/orange markets, it is imperative that farmers' access to appropriate market information is facilitated to guide decisions.

Households whose head's had formal occupation (e.g. teachers, local government employees and technicians), had better market access levels compared to those without (Table 2). Overall, formal employment elicited the highest (0.6) units increase in the extent of market access. This could be due to extra income regularly obtained from off-farm employment, plus the wide network outside the farm confines which enabled the households to acquire market information and position themselves for enhanced market access.

Although the physical market access facilitating infrastructure in Soroti District (radio and mobile networks, roads, storage and education facilities) was relatively more developed compared to Kaberamaido and Kumi Districts, findings showed that the extent of market access for households located in Soroti District was lower than for those located in Kaberamaido and Kumi Districts. This contradicts Baltenweck and Staal (2007) observation that the further the farm is from a large well established urban centre, the lower the market access. This could be due to the proximity of Kaberamaido and Kumi from the border posts and the low produce prices which discouraged the enlightened Soroti District household from selling their produce when appropriate. In addition, farmers from Soroti District had more and varied off-farm employment opportunities because it is relatively more urbanised and developed, 
which may have indirectly affected orange fruits production, and thus quantities available for sale. This too implies that, cooperation, coordination and collaboration among farmers and farmer groups across the orange fruits growing areas would enhance market access. So creation of networks across districts would enhance market access capacity for smallholders across the districts.

\section{CONCLUSION}

The institutional factors constraining farmer access to orange markets in Uganda include institutional belonging, market information and extension; while infrastructural factors include mobile phone and location of household. On the other hand, major socio-economic factors influencing access to orange markets include output, output price, age and occupation of household head, and household size. Thus the opportunities for unlocking the potential for smallholder orange market access lie in improving access to market information, mobile phones and increasing output.

\section{ACKNOWELDGEMENT}

We are grateful to the Carnegie Foundation and International Development Research Centre (IDRC) for providing the financial support for this research work. The University of Malawi, Lilongwe University of Agriculture and Natural Resources (LUANR) and the Regional Universities Forum for Capacity Building in Agriculture (RUFORUM) provided technical support.

\section{REFERENCES}

Abafita, J., Atkinson, J. and Kim, C.S. 2016. Smallholder commercialization in Ethiopia: Market orientation and participation. International Food Research Journal 23(4):1797-1807.

Acland, J.D. 1989. East African Crops: An introduction to the production of field and plantation crops in Kenya, Tanzania and Uganda. Food and Agriculture Organisation of the United Nations, Rome, Italy.

Agbola P.O, Adenaike T. and Babalola D.A. 2010. Determinants of farmer's access to output markets and the effects on income. A case study of Ikenne Local Government area, Nigeria. Journal of Life and Physical Sciences; ACTASATECH 3(2):33-39.

Ahmed, I.U., Ying, L., Bashir, K.M., Abid, M., Elahi, E. and Iqbal, A.M. 2016. Access to output markets by small farmers: The case of Punjab, Pakistan. The Journal of Animal and Plant Sciences 26(3): 787- 793, ISSN: 1018-7081.

Allegra, V., Zarbà, C., La Via, G. and Zarbà, A.S. 2019. Why the new orange juice consumption model favors global trade and growth in orange production. British Food Journal 121(9): 1954-1968. https://doi.org/ 10.1108/BFJ-05-2019-0316

Alobo, S., Akabway, S. and Ajambo, R. 2011. Market survey of citrus enterprise in Uganda. NAADS Secrtetariat, Ministry of Agriculture, Animal Industry and Fisheries, Uganda Government. Kampala, Uganda.

Ayoki, M. 2007. Agricultural market in Uganda: A Profile. Institute of Policy Research and Analysis, Munich Personal RePEc Archive (MPRA) Paper No. 80900. https://mpra.ub.uni-muenchen.de/80900/1/ MPRA_paper_80900.pdf

Baltenweck, I. and Staal, S. 2007. Beyond one-size-fits-all. Different market access measures for commodity systems in the Kenyan Highlands. Journal of Agricultural Economics 58(3):536-548.

Cameron, A.C. and Trivedi, P.K. 2005. Microeconometrics: Methods and applications. Cambridge, USA: Cambridge University Press.

Diao, X. and Hazell, P. 2004. Exploring market opportunities for African smallholders. International Food Policy Research Institute (IFPRI), Washington DC., USA.

Dormann, C., Elith, J., Bacher, S., Buchmann, C., Carl, G., Carré, G., Diekötter, T., García 
M.J., Gruber, B., Lafourcade, B., Leitão, P., Münkemüller, T., Mcclean, C., Osborne, P., Reineking, B., Schröder, B., Skidmore, A., Zurell, D. and Lautenbach, S. 2013. Collinearity: A review of methods to deal with it and a simulation study evaluating their performance. Ecography 36:27-46. 10.1111/j.1600-0587.2012.07348.x.

Ekesi, S. 2011. Combating Fruit Flies in Eastern and Southern Africa (COFESA): Elements of a Strategy and Action Plan for a Regional Cooperation Program. The World Bank, Washington DC. http:// w w w. gl obal hort . org/network communities/fruit-flies/ (accessed on 23 February 23, 2011).

Gabre-Madhin, E. and Haggblade, S. 2004.Successes in African Agriculture: Results of an Expert Survey. World Development 32 (5):745-766.

Gani, B. S. and Adeoti, A.I. 2011. Analysis of Market Participation and Rural Poverty among Farmers in Northern Part of Taraba State, Nigeria. Journal of Economics 2(1): 23-36.

Green, W.H. 2012. Econometric Analysis.7th edition. Upper Saddle River, NJ: Prentice Hall.

Hammouda, H., Karingi, S.N. and Perez, R. 2005. Unrestricted market access for subSaharan Africa: Important benefits with little cost to the QUAD. ATPC Work in Progress Paper Series No. 11, African Trade Policy Centre, Economic Commission for Africa, Addis Ababa, Ethiopia.

Harou, A. 2011. Smallholder market access. Policy Brief, Cornel University.

Kamara, A.B. 2004. The Impact of Market Access on Input Use and Agricultural Productivity: Evidence From Machakos District, Kenya. Journal of Agriculture and Food Science 2(2):77- 90.

Komarek, A. 2010. The determinants of banana market commercialisation in Western Uganda. African Journal of Agricultural Research 5:775-784. 10.5897/AJAR09.022.
Kongai, H. 2017. Analysis of citrus value chain, market access and supply response in Kyoga Plains Agricultural Zone, Uganda. PhD. Thesis, University of Malawi, Malawi. 220pp.

Kongai, H., Mangisoni J., Elepu, G., Chilembwe, E., Kwapata, M.B. and Makoka, D. 2011. Citrus value chain in Eastrn Uganda. African Crop Science Conference Proceeding 10:19 - 21.

Kongai, H., Mangisoni, J., Elepu, G., Chilembwe, E., Kwapata, M.B. and Makoka, D. 2018. Analysis of citrus value chain in Eastern Uganda. African Crop Science Journal 26(3):417-431.

Mahele, G.F. 2007. Factors affecting commercialization of smallhholder farmers in Ethiopia. The case of North Omo Zone, SNNP region. Paper presented at the Fifth International Conference on the Ethiopian Economy, Addis Ababa., Ethiopia.

Markelova, H. and Meinzen-Dick, R. 2009. Collective Action for Smallholder Market Access. CGIAR Systemwide Program on Collection Action and Property Rights. Policy Brief No. 6. http://www.capri. cgiar.org/pdf/polbrief_06.pdf (accessed 5 April 2011).

Ministry of Tourism, Trade and Industry 2005. The Marketing and Agro-processing Strategy (MAPS), Kampala, Uganda.

Mwakaje, A.G.O. 2010. Information and communication technology for rural farmers market access in Tanzania. Journal of Information Technology Impact 10(2):111-128.

Mwaura, S.N., Muluvi, A.S. and Mathenge, M.K. 2014. African leafy vegetables and household wellbeing in Kenya: A disaggregation by gender. Current Research Journal of Social Sciences 6(4):82-94. Maxwell Scientific Organisation.

Mwesigwa, D. 2018. Using farmer groups to empower small-holder rural farmers in Hoima district, mid-western Uganda. Research Gate. https://www.researchgate. net/publication/324480595. 
Nee, V. and Young F.W. 1991. Peasant Entrepreneurs in China's "Second Economy. An Institutional Analysis. Economic Development and Cultural Change 39(2):293-310.

Obi, A. and Pote, P. 2012. Technical constraints to market access for crop and livestock farmers in Nkonkobe Municipality, Eastern Cape province: In Unlocking markets to smallholders. Lessons from South Africa. Mansholt Pubications series (10). Wageningen Academic Publishers, The Netherlands.

Onek, H. 2014. Teso: Kaberamaido District hazard, risk and vulnerability profile. United National Development Programme (UNDP).

Ouma, E. and Jagwe, J. 2010. Banana Value Chains in Central Africa: Constraints and Opportunities. 3rd African Association of Agricultural Economists and 48th Agricultural Economics Association of South Africa Conference. http:// ageconsearch.umn.edu/bitstream/96169/2/ 114.BananavaluechainsinCentralAfrica.pdf

Palinkas, L., Horwitz, S., Green, C., Wisdom, J., Duan, N. and Hoagwood, K. 2015. Purposeful sampling for qualitative data collection and analysis in mixed method implementation research. Administration \& Policy. In: Mental Health \& Mental Health Services Research 42(5):533-544.

Plan for Modernisation of Agriculture (PMA). 2009. Citrus market study report for Teso Sub-Region. Ministry of Agricultural Animal Industry and Fisheries, Entebbe, Uganda.

Rudaheranwa, R., Bategeka, L., Banga, M. and Mukungu, A. 2003. Supply response of selected export commodities in Uganda. Research Series No. 36, Economic Policy Research Centre. Kampala, Uganda.

Siziba, S., Nyikahadzoi, K., Diagne, A., Fatunbi A.O. and Adekunle, A.A. 2011. Determinants of cereal market participation by sub-Saharan Africa smallholder farmer. Journal of Agriculture and Environmental Studies 2(1):180-193.

Sonko, R., Njue, E., Ssebuliba, J.M. and de Jager, A. 2005. A report of the study of the Horticultural Sector in Uganda. Pro-Poor Horticulture in East Africa and South East Asia. 78pp.

Turner, T. and Burri, B. J. 2013. Potential nutritional benefits of current citrus consumption. Agriculture 3:170-187. doi:10.3390/agriculture3010170.

Uganda Development Cooperation. 2012. Teso citrus feasibility study, Deloitte (Uganda) Ltd, Kampala, Uganda.

Uganda Investment Authority (UIA). 2009. Investing in Uganda: Investment potentials in citrus fruit farming. The Investment Centre, Ministry of Finance, Planning and Economic Development, Kampala, Uganda. Uganda Investment Authority (UIA). 2016. Teso investment profile. The Investment Centre, Ministry of Finance, Planning and Economic Development, Kampala, Uganda. Woodridge, J. 2002. Econometric Analysis of Cross-section and Panel Data. MIT Press, USA.

Zivenge, E. and Karavina, C. 2012. Analysis of factors influencing market channel access by communal horticulture farmers in Chinamara District, Zimbabwe. Journal of Development and Agricultural Economics 4(6):147-150. 